\title{
Erratum to: Chemical changes in soil and soil solution after calcium silicate addition to a northern hardwood forest
}

Youngil Cho $\cdot$ Charles T. Driscoll .

Chris E. Johnson - Thomas G. Siccama

Published online: 18 June 2010

(C) Springer Science+Business Media B.V. 2010

\section{Erratum to: Biogeochemistry \\ DOI 10.1007/s10533-009-9397-6}

The author's would like to point out an error in Table 1. In the Method column, the concentration number of $\mathrm{CaCl}_{2}$ should read $0.01 \mathrm{M}$ (this is correct for $\mathrm{pH}_{\mathrm{s}}$ ).

The online version of the original article can be found under doi:10.1007/s10533-009-9397-6.

Y. Cho $(\bowtie) \cdot$ C. T. Driscoll · C. E. Johnson

Department of Civil and Environmental Engineering,

Syracuse University, 151 Link Hall, Syracuse,

NY 13244, USA

e-mail: yicho@syr.edu

T. G. Siccama

School of Forestry and Environmental Studies, Yale

University, Sage Hall, 205 Prospect Street,

New Haven, CT 06511, USA 